\title{
THE BIOLOGY OF NONFRUGIVOROUS TEPHRITID FRUIT FLIES
}

\author{
D. H. Headrick and R. D. Goeden \\ Department of Entomology, University of California, Riverside, California 92521
}

KEY WORDS: ecology, evolution, morphology, behavior, trophic strategies

\begin{abstract}
This review is the first comprehensive treatment of the biology of nonfrugivorous fruit flies of the family Tephritidae. Feeding habits of destructive and useful species, morphology of immature stages, and hypotheses regarding structural homology and the evolutionary biology of nonfrugivorous tephritids are reviewed, including zoogeography and theories involving resource heterogeneity, guild structure, resource partitioning, resource utilization, facultative niche exploitation, extrinsic and intrinsic factors, host associations, seasonal distribution and phenology, aggregative and circumnatal life history strategies, voltinism, diapause, aestivation, oviposition site, clutch size, and supernumerary oviposition.
\end{abstract}

\section{PERSPECTIVES AND OVERVIEW}

There is no comprehensive family-wide review of the biology of tephritid fruit flies. Reviews exist that focus on economically important taxa within the family $(2,8,105,127)$, discuss regional faunas $(9,14,20,64,86,100,126)$, or treat one related subject such as gall formation by tephritids (18) or tephritids used in biological control of weeds $(67,85,118,121)$. These reviews are extremely useful and taken together provide good coverage of the Tephritidae, except for a comprehensive picture of the biology and ecology of nonfrugivorous species.

Our goal is to review important aspects of nonfrugivorous tephritid biology and ecology, to highlight relevant hypotheses that have been developed, and to suggest where future research may lead. Accordingly, we do not re-review the 
systematics or biological control literature on nonfrugivorous Tephritidae, except where selected topics relate to biological and ecological hypothesis development and testing. Although nonfrugivorous tephritids are found throughout much of the temperate and subtropical zones of the world, the preponderance of research has focused on Nearctic and Palearctic species, which this review reflects.

This review is based on the belief that hypotheses involving the biology and ecology of Tephritidae should more fully take into account knowledge on subordinate taxa from throughout the family and not just rely on data gathered on economically important species in areas where they occur as pests. One of the greatest roadblocks to the development and testing of hypotheses regarding the evolutionary biology and ecology of the Tephritidae is the current lack of a comprehensive phylogenetic analysis (15). When such a treatment is developed (61), significant advances in our understanding of the biological and ecological features of this family will certainly follow.

The study of tephritid biology contributes substantially to the validation of species and to recognition of species groups and their classification $(15,126)$. Furthermore, the family is divided into two major groupings based primarily on their food type (133). Three subfamilies of Tephritidae are recognized, the Dacinae, the Trypetinae, and the Tephritinae (15), but the classification of subfamilies is currently under revision. The Dacinae and Trypetinae use the fleshy fruit of host plants from a wide variety of families as larval food sources (127). The Tephritinae use the vegetative parts of host plants and flower heads as larval food, and many form galls in and on these plant structures $(15,126,133)$. The tephritines, with some exceptions, feed solely on plants in the family Aster-

aceae. This has led to some confusion regarding usage of "specialist" and "generalist" descriptions when further distinguishing the biological characteristics of the tephritines and trypetines, as is discussed below in the section on host associations.

\section{ZOOGEOGRAPHY}

The Tephritidae (Muscomorpha: Tephritoidea) is one of the larger families of Diptera, with $\sim 4200$ described species in $\sim 500$ genera (15). The subfamily Tephritinae is comprised of $\sim 200$ genera worldwide with $\sim 1800$ species $(15,16,127)$. The family is distributed in the temperate, subtropical, and tropical regions of the world, with the greatest diversity of species occurring in the Tropics $(9,15,64-66,126)$.

Fossil evidence of tephritids is rare (103). Three species are known from compression fossils and two species from amber (103 and citations within). The oldest specimen, Protortalotrypeta grimaldii, is from Dominican amber 
and is estimated to be 25 million years old (103). Freidberg (19) described a Ceratitis sp., possibly C. rosa, from amber from Tanzania that is about 3 million years old. Both of these genera are trypetines, but Protortalotrypeta is a New World genus, whereas Ceratitis is an Old World genus $(9,19,62,63)$. The Tephritidae are considered to have originated in the paleotropics, presumably post-Gondwanan, because of the high species diversity encountered there (103). The zoogeography of extant species and fossil evidence suggest that the genera of Trypetinae and Dacinae represent the ancestral lineages of the family, whereas the Tephritinae appeared later with species diversity concentrated in the subtropical and temperate regions of the world (103).

\section{FEEDING HABITS-DESTRUCTIVE AND USEFUL SPECIES}

The nonfrugivorous appellation refers to species of tephritids whose larval foods are plant parts other than fleshy fruits (133). Most nonfrugivorous tephritids are not economically important, but a few species attack cultivated plant species (see 127 for review).

Some tephritid species have been used as biological control of weeds agents, with most introductions originating from Europe and North America. The introductions have been chronicled by Goeden (21), Harris (67), Julien (85), and Turner (118).

\section{MORPHOLOGY OF THE IMMATURE STAGES}

A comprehensive review of tephritid larval morphology is given by Ferrar (13). We highlight more recent findings and discuss them relative to newly developed hypotheses. The development of the science of tephritid larval morphology is hindered by a lack of resolution in anatomical homology. This is a problem not easily resolved, as it plagues the higher Diptera as a whole. Without reliable evidence to support the homology of larval structures, application of terminology becomes an exercise in frustration.

Mouth hooks are exemplary of this difficulty. There is no compelling evidence to show that they are either mandibular $(96)$ or maxillary $(98,99)$ in origin, that they represent a combination of the two (11), or that they are of some novel origin in the larval form (110). Thus, naming conventions have had to adopt terms without anatomical implications toward homology, such as "mouth hook." Similarly, terms such as dorsal sensory organ rather than antenna, or anterior sensory lobe rather than maxillary palp, are commonly used, as the homologies of these structures remain unresolved. Considerable research in this area is needed that encompasses the Muscomorpha as a whole - a rather 
daunting task! Until such time, we have opted to retain the use of generic (noncommittal) terminology.

\section{Egg}

The study of nonfrugivorous tephritid egg morphology has largely been confined to the description of surface features. The ultrastructure of a few trypetine species has been examined with transmission electron microscopy $(97,101,102$, 128), and we assume that the ultrastructural detail is consistent within the family.

Tephritid eggs are elongate ellipsoidal in shape and thus have only a single primary axis. At one end, the egg bears a pedicel, and by convention this is termed the anterior end of the egg; "pedicel-end" is also used. The pedicel bears the micropyle and the aeropyles. Typically, the micropyle is located on the apex of the pedicel and may have a single or multiple openings. The aeropyle pores circumscribe the pedicel on its lateral margin. The arrangement of the micropyle and aeropyles is similar among the nonfrugivorous species studied. The pedicel may be only a slight projection $(13,88)$, but it may also occur as an elongated stalk nearly as long (55-57) or longer than the body of the egg (74). The end opposite the pedicel is typically smooth and bluntly rounded without any external openings or structures (see 119 for an exception). Again, by convention, it is termed posterior; "basal-end" is also used.

Insect egg orientation has long been an elusive morphological concept to verify. The eggs of all tephritid species studied thus far develop inside the ovariole with the pedicel oriented toward the ovary terminus. This orientation facilitates the functions of fertilization and oviposition. Fertilization takes place through the micropyle as the egg passes through the median oviduct. The basal end exits the gonopore first near the end of the aculeus that is inserted into plant tissues during oviposition (79).

Embryogenesis proceeds after oviposition, and the head of the embryo develops oriented toward the pedicel. However, in many species, the embryo turns $180^{\circ}$ before eclosion and exits the egg through the basal end. This apparently serves to position the embryo so that the plant tissue is encountered immediately upon eclosion (35).

The surfaces of eggs have polygonal, typically hexagonal, reticulations or bas-relief-type ridges. These ridges represent the outline of the follicle cells responsible for laying down the chorion $(87,102)$. These reticulations may be prominent and bear additional structural ornamentation, as in Tephritis baccharis (35). The surface features of the egg are most strongly developed at the pedicel end and diminish, often to a smooth surface, near the basal end, as reported in Aciurina thoracica (78). Goeden \& Headrick (35) hypothesized that because the pedicel end of the egg is left exposed to facilitate gas exchange and 
the basal end is inserted into plant tissues, the pedicel would need greater structural support to protect the aeropyles and associated respiratory channels from distortion. Another hypothesis developed for eggs of fruit-infesting species is that the basal end is structurally weaker to facilitate embryo eclosion (97).

\section{Larvae}

Three free-living instars exist for nonfrugivorous tephritids. The only known exceptions are Urophora jaceana and Urophora cardui (119), in which the first instar remains in the egg and exits as a second instar. Procecidochares minuta forms axillary bud galls on its host, Chrysothamnus nauseosus, but overwinters for several months as a first instar inside its chorion inside the incipient gall (DH Headrick, RD Goeden, and coworkers, unpublished data).

The external anatomy of the larvae of nonfrugivorous tephritids has only recently been examined in detail, and at least partial descriptions based primarily on scanning electron micrographs for 25 species have been published to date by Headrick, Goeden, and coworkers (33-41, 55-60, 74, 77, 78, 80-82, 88, 89; also see 13 for an annotated list of species described before 1987). By comparison, White \& Elson-Harris (127) have developed an atlas of immature morphology based on the third instar of 34 economically important species.

Several structures have been newly identified for nonfrugivorous species. These include the median oral lobe (74), the presence of functional lateral spiracles accompanied by a variable number of sensilla (77), and several sensilla associated with the sensory organs of the gnathocephalon $(60,74,77,88)$.

The median oral lobe was first described for Paracantha gentilis (74) and has subsequently been found in every nonfrugivorous species examined by Headrick, Goeden, and coworkers (33-41, 55-60, 74, 77, 78, 80-82, 88, 89) and others $(4,5)$ to date. The median oral lobe is an independently movable, uniquely musculated and innervated structure consisting of a dorsal sclerite and a ventral lobe (cf 78 for detailed anatomical drawings). The median oral lobe is absent in all trypetine or dacine species examined thus far. The median oral lobe appears to function in rendering fluids from plant tissues that have been abraded by the mouth hooks.

Tephritids have distinct anterior prothoracic spiracles and posterior spiracles. The presence of lateral spiracles was noted in the puparium of Rhagoletis pomonella by Snodgrass (109) from the presence of small tracheae associated with the cast exuviae of the prepupal integument on the inside of the puparium wall. However, Snodgrass (109) was unable to locate the outer spiracular openings with conventional microscopy, and thus he assumed they were present but did not describe them. With the aid of scanning electron microscopy, the lateral spiracles have been located on the meso- and metathoracic segments and the abdominal segments, excluding the caudal segment, which bears the posterior 
spiracles (74). The lateral spiracles are always located along the lateral midline near the anterior portion of a segment, and they have a variable number of associated campaniform sensilla posteriorad of the spiracle. The number of sensilla ranges from one in some Aciurina $(55-57)$ and Trupanea $(77,88)$ species to as many as four in Stenopa affinis (33). When more than one sensilla is present, they are typically arranged along a dorso-ventral axis adjacent to the spiracle.

\section{Puparium}

The puparium is the hardened, penultimate larval integument and is unremarkable in its external morphology in nonfrugivorous tephritids. The duration of the prepupa within the puparium is unknown. The prepupal integument is shed and adheres to the inner wall of the puparium. The pupa forms within the puparium after the prepupal molt. The pupa develops independently of the puparium and has bilobed thoracic spiracles for respiration (74). Headrick \& Goeden (74) and Goeden \& Headrick (36) showed that the larval tracheae adjacent to the anterior and posterior spiracular openings remain open, thus allowing for gas exchange for the developing pupa within the puparium.

Goeden \& Headrick (36) reported a prepuparial stage in which the mouthparts are invaginated and the integument takes on a waxy appearance, but the processes of integument hardening and darkening are delayed. The latter processes may be triggered by changing environmental conditions by overwintering prepuparia of certain Neaspilota (36) and North American Urophora species, especially those found at higher altitudes (41). The prepuparial stage may be related to the physiological and morphological changes that take place in such well-known cold-hardy species as Eurosta solidaginis and European Urophora spp. (see Diapause and Aestivation below).

\section{ECOLOGICAL THEORY}

Zwölfer (130-135) has helped to develop our understanding of the theoretical ecology and biology of nonfrugivorous tephritids through his extensive studies of thistle-infesting species of the Palearctic region. The major themes that he and his coworkers have developed include tephritid trophic strategies, trophic guilds, resource utilization, and the evolution of tephritid-host plant interactions.

The driving force behind early development of these ideas was research conducted in Europe for biological control of adventive species of thistles and knapweeds in North America. The ability to characterize or predict the "best-suited" natural enemy meant defining the biology and ecology of candidate species in their area of origin-Europe, in the case of weedy thistles and knapweeds $(129,135,138)$. The following categories have served as foci for research and 
the development of hypotheses concerning nonfrugivorous tephritid biology and ecology.

\section{Resource Heterogeneity}

Resource heterogeneity characterizes the feeding niches occupied or otherwise exploited by nonfrugivorous tephritid larvae. The host ranges of nonfrugivorous species are limited mainly to the Asteraceae, with some tephritids attacking a wide range of species, genera, and tribes within this largest of higher plant families (7, 22, 24, 27, 29-32, 122, 129; see Host Associations below). The Asteraceae are structurally diverse herbaceous and woody plants and shrubs, which are characterized by their flower heads or capitula (7).

Nonfrugivorous species feeding on Asteraceae infest flower heads, mine branches or stems, feed on rosettes, mine crowns, and form galls on both aerial and subterranean vegetative plant tissues $(15,33-35,37-41,59,77,78,80,81$, $126,129,133)$. Flower head-infesting species feed on florets, ovules, soft achenes, and/or receptacle tissues. However, in North America few native species are known to form galls within flower heads in comparison with European tephritids (15). The closest is the occasional, small, hollow gall of a sin-

gle floret of $C$. nauseosus formed by an individual larva of Procecidochares n. sp. 1, nr. minuta (RD Goeden \& coworkers, unpublished data). Also, the gall of Procecidochares n. sp. 2, nr. minuta on Xylorhiza (= Machaeranthera) tortifolia is the hollowed out calyx of a flower head (RD Goeden \& coworkers, unpublished data). Examples of nonfrugivorous tephritids that attack host plant species outside the Asteraceae were reviewed by White (126), Ferrar (13), and Foote et al (15).

\section{Guild Structure}

Because the niches occupied by nonfrugivorous tephritids are structurally diverse, these flies are often only part of the guild of phytophagous insects that feed upon a given plant structure, e.g. flower head-feeding or stem-mining guilds $(42-54,83)$. In southern California, the thistle flower head-infesting guild is comprised of up to four species: Rotruda mucidella (Lepidoptera: Pyralidae), Platyptilia carduidactyla (Lepidoptera: Pterophoridae), Orellia occidentalis, and $P$. gentilis (Tephritidae) (50). From one to four of these species may be present in a local population of thistles, thus leaving known trophic niches at least partially or temporarily vacant. The European thistle flower head fauna is numerically larger than the North American fauna, and niche diversification includes trophic strategies not found in North America (134). This disparity among guild structure supports hypotheses developed by Lawton $(94,95)$ and Compton et al (10) that phytophage communities often fail to converge in structure despite similar resources on different continents. 
Zwölfer (134, p 412) captured the essence of guild structure and intra-guild interactions when he wrote concerning the characteristics of thistle flower head guilds in Europe: “...it has been found that coexisting phytophagous species differ in parts of their ecological niches. If coexisting species belong to different families or orders, they are exposed to different sets of parasitoids. Niche diversification is further increased by differences in larval feeding habits, host ranges, voltinism, degree of aggregation, and hibernation sites. Thus even if 12 phytophagous species coexist in a flower head population, the single members of the guild can be distinguished by traits of their life history, trophic strategies and mortality factors."

As more species of tephritids are studied, the subtleties of niche diversification or resource partitioning become better elucidated and better appreciated.

\section{Resource Partitioning}

The temporal and spatial partitioning of resources among guild members is often precise and highly selected for. Again, drawing from a North American thistle flower head example, the larvae of $P$. gentilis feed centrally in a flower head on ovules, achenes, and receptacle tissues, even when no other members of the guild are present $(76,111)$. The larvae of $R$. mucidella attack thistle flower heads at a later developmental stage and feed peripherally on the achenes and receptacles. If a larva of $P$. gentilis pupariates near the periphery of the flower head, the larva of $R$. mucidella will consume any such puparium encountered. Thus, there is a strict spatial separation of resources within this guild and a high selection pressure to maintain it $(75,76)$.

Resources are known to be partitioned spatially, temporally, and, as reported recently for Aciurina spp. in California, altitudinally. Of these Aciurina spp., A. ferruginea, A. idahoensis, A. michaeli, and A. semilucida all form axillary bud galls on their sole shared host plant Chrysothamnus viscidiflorus Nuttall. However, adults of $A$. idahoensis and A. semilucida emerge and reproduce early in the spring at low altitudes $(<1800 \mathrm{~m})$, whereas A. ferruginea and A. michaeli emerge and reproduce in the summer at higher elevations (55-57).

\section{Resource Utilization}

Resource utilization is the percentage of the resource unit that is attacked/ consumed per unit sample (134). The number of species occupying a resource unit (equal to the number of species in a guild) is termed species packing. Zwölfer (135) reviewed resource utilization and species packing in European thistle-insect systems where tephritids are often the dominant phytophage.

There are relatively few studies of resource utilization and species packing outside of Europe. Predispersal seed predation of Cirsium canescens by Paracantha culta and O. occidentalis was studied on the Great Plains of North 
America by Lamp \& McCarty (93). Resource utilization by P. culta was such that as the number of larvae per flower head increased, the number of seeds destroyed decreased; however, $O$. occidentalis showed a linear relationship in the number of larvae to seeds destroyed. The tephritids were two of a total of three species comprising the flower head-feeding guild. In insect-plant systems without a clearly dominant phytophage, the average level of resource utilization increases with increasing values of species packing (135).

Resource utilization relative to plant energy flow and host consumption in phytophagous guilds with tephritid members has been little-studied in North America. However, the concepts of resource utilization and species packing have been applied to results of several faunistic surveys involving plants that host one to several species of tephritids $(49-52,75)$. Comparison of speciespacking statistics between North American and European faunas showed significant differences in guild saturation, with the former faunas having far more empty niches. These comparative data have application in pre-release surveys, natural enemy recruitment, and post-release monitoring for biological control of weeds. Recently, focus has rested on the need for studies of biological diversity. The use of resource utilization and species packing statistics may enhance the comparative value of regional plant-based biodiversity studies.

\section{Facultative Niche Exploitation}

Some nonfrugivorous tephritids channel assimilates into their food niches. Galls within flower heads act as metabolic sinks, which draw nutrients from the host plant that are converted into gall tissues and subsequently into larval biomass $(70,71)$. Romstöck (106) showed that larvae of Tephritis conura induced the formation of undifferentiated callus tissues resulting from feeding on the receptacle. This callus tissue also acted as a metabolic sink to maintain nutrient flow, thus augmenting the resource value of the flower head.

Similarly, scoring of the receptacle by $P$. gentilis augmented the resources available to developing larvae within the flower head by creating cup-like depressions in the surface of the receptacle that filled with sap that was subsequently fed upon by the larvae. This was shown to be a density-dependent change in feeding habit by third instars when flower heads were occupied by three or more $P$. gentilis larvae $(75,76)$. This change in feeding habit has now been shown to occur for other nonfrugivorous tephritid species $(25,28,34,36$, $37,39,41,77,81)$.

Other methods of facultative niche exploitation have been discovered among nonfrugivorous tephritids; some were reviewed by White (126). The flower head-infesting Trupanea conjuncta is a facultative gall former on its nonflowering desert host during drought (23), whereas Tephritis stigmatica alternates between a spring gall-forming generation and a late-summer and fall 
flower head-feeding and gall-forming generation (26). Similarly, Tephritis arizonaensis is bivoltine in southern California, with the overwintering generation developing in branch tip mines and the second generation developing in the flower heads of its host, Baccharis sarothroides (37). E. solidaginis, once thought to be an obligate gallicolous species, can infest its host, Solidago canadensis, without forming a gall, and the non-gall-forming individuals apparently escape most parasitism and predation normally associated with gallforming larvae (112). More of these facultative modes of feeding and alternative developmental strategies will certainly be discovered as more nonfrugivorous tephritids are studied.

\section{Extrinsic and Intrinsic Factors}

The ecological constraints of host acceptance or host-range changes were divided into two categories, extrinsic and intrinsic factors, by Zwölfer $(132,133)$. Extrinsic factors involve the adult stage, and they include dispersal to and behavioral acceptance of new hosts, timing the life cycle to include new hosts, and overcoming ovipositional constraints in new hosts. Intrinsic factors involve the immature stages and include enemy-free space, intraspecific and interspecific competition, nutritional suitability, and timing of diapause.

Little research has been conducted on host range expansion or behavioral acceptance of new hosts by nonfrugivorous tephritids. Craig et al (12) presented evidence that host-plant fidelity and voltinism were two factors that help to maintain isolation between two sympatric populations of $E$. solidaginis. Recently, Knio et al (89) demonstrated that host-plant fidelity and temporal ovipositional constraints were two factors that also maintained isolation between sympatric sibling species of Trupanea.

Considerable research has been conducted with nonfrugivorous tephritids regarding enemy-free space, intraspecific and interspecific competition, and timing of diapause. For example, field studies of E. solidaginis galls on Solidago spp. showed that small galls were more vulnerable to attack than larger galls by the parasitoid Eurytoma gigantea. Fields with small mean gall size had higher rates of parasitism. However, insectivorous birds that fed on gall contents were more likely to attack large galls than small ones, and fields with an overall larger mean gall size suffered heavier mortality from birds. The net directional selection imposed on gall size varied more strongly with parasitoid attack than with bird attack, but neither birds nor $E$. gigantea show simple density-dependent attack patterns (123-125).

The larvae of T. conura live gregariously in flower heads of Cirsium heterophyllum. The endoparasites, Eurytoma nr. tibialis and Pteromalus caudiger, parasitize larvae within the flower head. The responses of the parasitoids to different host-patch sizes were investigated at the host population level. The 
overall probabilities of parasitism were independent of host numbers per flower head or showed a tendency toward inverse density dependence for both parasitoids. Ovipositor lengths indicated that parts of the flower head were refuges for $T$. conura, i.e. accessibility differed by location of larvae within the head (107).

Pteromalus coloradensis vigorously probes thistle flower heads containing $P$. gentilis larvae. The larvae of $P$. gentilis feed centrally in flower heads of Cirsium californicum and Cirsium proteanum. Thus, flower head size, parasitoid ovipositor length, and location of the larvae within a head influenced percentage parasitism (73).

Hawkins (72) determined that of the 34 species of tephritids examined, the endophytic gall-forming species supported more than twice as many parasitoid species as endophytic non-galling species. His conclusion was that escape from parasitism does not necessarily follow development of concealed feeding habits, especially gall formation.

\section{Host Associations}

Previous reviews by Bateman (2) and Christensen \& Foote (8) indicated that tropical tephritid species were polyphagous, infesting fruits from plant species in several families, whereas temperate species (cf Rhagoletis spp.) were considered monophagous. True monophagy is not uncommon among nonfrugivorous Tephritidae $(14,24,27-29,35,55,56,58,122)$. However, many species are nearly monophagous or narrowly oligophagous, feeding on two to several species within a genus or a few genera within a subtribe, respectively.

Host ranges for most genera of nonfrugivorous Tephritidae are only now being defined. This process is complicated by erroneous host records for misidentified tephritid species and host plants and by sweep records for adult tephritids from plant species merely assumed to be hosts. Sweep records become ensconced in the host literature and often are poor indicators of true larval host affinities $(22,29,48)$.

Polyphagy in the sense of feeding on many hosts does occur in nonfrugivorous tephritines, although these hosts are all restricted to the Asteraceae. Considerable confusion results from another definition for polyphagy, which according to some authors means feeding on multiple plant families. However, because the Asteraceae is the largest plant family, with 23,000 species in 1,535 genera in 17 tribes worldwide (7), consideration of certain species of tephritids, which are known to feed on over 100 species of host plants from several tribes within the family, as specialized and nonpolyphagous in comparison to frugivorous species that attack a few hosts in more than one plant family seems more semantic than precise. For example, Trupanea jonesi feeds in the flower heads of at least 101 species in 45 genera, 8 tribes, and 17 subtribes in the Asteraceae, 
and, for this reason, Goeden (22) adopted "generalist" to designate such species among nonfrugivorous tephritids. He also defined oligophagous species as attacking more than one genus, distinguished narrowly and broadly oligophagous species, and defined monophagous and nearly monophagous species as feeding on one or more host species, respectively, within a single genus $(22,29)$.

Individual tephritid genera may contain species that are true and near monophages, broad and narrow oligophages, and generalists $(22,24,27,29-31)$. Other tephritid genera are more specialized on certain host taxa [for example, Urophora spp. on the subtribe Solidagininae of the tribe Astereae in North America (24)].

\section{Seasonal Distribution and Phenology}

Previous workers also divided the tephritids into two groups based on the physiological and ecological characteristics of economically important species. One group was univoltine, had a winter diapause, and inhabited temperate areas (e.g. Rhagoletis spp.). The other group was multivoltine, lacked diapause, and inhabited tropical and subtropical regions (Bactrocera, Dacus spp.). Bateman (2) additionally stated that the temperate univoltine species would have brightly colored markings and banded wings, their sexes would meet on the host fruit when the female arrived for oviposition, and no sex attractant pheromone would be produced. Conversely, the tropical multivoltine species would have sex pheromones, mating would occur away from the female-required resource, the wings would be less heavily marked, and courtship would be less elaborate.

These groupings were of limited application, especially relative to nonfrugivorous species (79). In their diversity, nonfrugivorous tephritids are monophagous to quasipolyphagous generalists, their body markings or colors are dull to bright, their wing markings are hyaline to virtually completely infuscate, pheromones are an important component of their mating systems, and they have from one to four or even more generations per year. Thus, all tephritids do not easily separate into the two groups based upon frugivorous species characters.

We redefined the life history strategies of nonfrugivorous tephritids and placed greater emphasis on phenology than on voltinism or trophic affinities. In this scheme the tephritids again divide into two groups: One is aggregative, the other is circumnatal (79).

AGGREGATIVE LIFE HISTORY STRATEGY Adults emerge and remain in reproductive diapause for differing durations and may be so up to a year in some univoltine species; typically their host plants are not in a stage that is suitable for oviposition upon emergence. Reproductive diapause for some species is nonexistent or is short in duration, as the multivoltine adults cycle on a succession of newly blossoming alternate hosts until the last generation diapauses 
and overwinters; others cycle as the same host blooms later at ever higher elevations or latitudes. Sometime later, adults return to aggregate on their $\mathrm{F}_{1}$-generation host plants, when these plants are again in a stage suitable for oviposition, and proceed to mate and oviposit. The larvae feed and pupariate within a short time frame, which is typically about as long as the reproductive growth period of the host plant, and thus, adults emerge shortly thereafter. One feature of this life history strategy is that adults return to their $F_{1}$-generation host plants, sometimes nearly a year later to begin the reproductive phase of their life cycle $(90,130,131)$. These tephritids exhibit several different kinds of trophic strategies, including floret/achene/ovule feeding, facultative gall formation, alternation of gall-forming and florivorous generations, and stem and crown mining.

CIRCUMNATAL LIFE HISTORY STRATEGY Circumnatal species typically are gall formers. Adults emerge at a time when their host plant is in a stage suitable for oviposition. They are proovigenic or reproductively mature soon after their emergence and proceed to copulate and oviposit. They remain on their natal host plant or on nearby host individuals and oviposit into axillary buds on the current season's branch and stem growth. The larval stages are typically long in duration, as gall formation proceeds over most of the year, although some species are facultatively bivoltine or even trivoltine $(26,35,59,60)$.

\section{Voltinism}

Some individuals in a population will vary considerably in the timing of their development and life cycle. White (126) pointed out that some individuals of tephritid populations delayed adult emergence from puparia for up to 2 or 3 years depending on their response to local conditions. The role of "partial" populations in local species distribution and abundance is in need of further field research. Having a small portion of a local population emerge and reproduce a partial second generation [cf T. baccharis (35)], or conversely delay its development [cf Procecidochares stonei (60)], is of adaptive significance for tephritids that live in areas that experience harsh climatic conditions such as regular droughts $(23,58)$. Also, species adapted to feed on plants that colonize disturbed or burned areas have evolved to exploit resources that may change drastically in availability from year to year $(74,75,80)$.

Voltinism, timing of emergence, and duration of ovipositional suitability of the host plant has special significance for tephritid species imported for biological control of weeds. Varying percentages of local populations of adults of Urophora affinis and Urophora quadrifasciata emerged to create up to three generations per year. Differences in voltinism and associated survival strategies served as key factors in the niche separation of the two species (113). 


\section{Diapause and Aestivation}

Most studies on diapause involve E. solidaginis or Urophora spp. introduced from Europe into North America for biological control of weeds. Studies on cold hardening of E. solidaginis have been reviewed by Storey \& Storey (115) and Baust \& Nishino (3). This species is freeze-tolerant and overwinters as a third instar. The gall provides thermal buffering during autumn before the insect is physiologically fully hardened. The gall freezes slowly and maintains the larva at $0^{\circ} \mathrm{C}$, an optimal temperature for physiological production of cryoprotectant compounds such as sorbitol and glycerol. Production of cryoprotectants shows a cycling response that appears to be related to developmental changes and seems to be under endocrine control (84).

The ability to overwinter in the plains and upper midwest of North America is of significant concern for tephritid species introduced for biological control of weeds. U. affinis and U. quadrifasciata introduced for control of spotted knapweed have supercooling capacities, but $U$. affinis was significantly better adapted than U. quadrifasciata. Super-cooling is the temperature at which body water spontaneously freezes. Both imported fly species can be expected to survive the winter in most areas of the northern United States, but only $U$. affinis may persist in the colder areas of eastern Montana and the upper midwest (114).

\section{BIOLOGY OF THE IMMATURE STAGES}

The Tephritidae also have been grouped into three categories based on their trophic strategies (133). Category I types are polyphagous fruit-infesting species; category II types are specialist fruit-infesting species. The nonfrugivorous tephritines belong to category III. Generalizations about the biological habits of flies in these categories have remained unchanged and, for the majority of nonfrugivorous species, are still relevant. According to Zwölfer (133), category III tephritids lay between 50 and 150 eggs over a lifetime; larvae develop in 20-40 days and usually pupariate inside the host; univoltine species may remain associated as immatures with the host for more than 300 days; and adults usually are short-lived (25-30 days), except for those species that overwinter as adults $(200+$ days). Furthermore, some species in category III hibernate as larvae or pre-puparia and have a short puparial period of 15-25 days; others overwinter as puparia. White (126) added that nonfrugivorous tephritids of Britain typically do not feed on more than two host plant genera; for North American species studied to date, this differs considerably $(15,22,24,27,29-31,122$; see Host Associations, above).

The major biological themes for defining category III tephritids are reproductive potential, developmental duration, adult longevity, voltinism, and 
host-plant associations. These themes were, again, born from a biologicalcontrol-of-weeds perspective and were intended to direct research focus to those areas that would provide data for selection of effective biological control agents $(68,69,138)$.

\section{Egg}

Egg biology can be subdivided into the following: $(a)$ oviposition site/trophic niche, $(b)$ clutch size, and $(c)$ supernumerary oviposition.

OVIPOSITION SITE/TROPHIC NICHE The eggs of nonfrugivorous tephritids are placed on or between flower head or bud parts or into the living plant tissues of these parts [cf Goeden \& Teerink (56) for an exception]. The most common oviposition sites are terminal or axillary buds on aerial stems or branches for gall formers and immature flower heads. One known exception is Procecidochares anthracina, which lays its eggs in axillary buds on shoots arising from subterranean rhizomes, and its galls subsequently develop below ground (59).

Nonfrugivorous tephritid eggs are placed in or near the larval food source by use of the appendicular ovipositor. The aculeus may pierce plant tissues to gain access to a particular area for egg deposition; however, little necrosis of plant tissues usually results from such oviposition [see Goeden et al (39) for an exception]. Avoidance of physical damage to the host plant during oviposition is sometimes a factor if the host plant secretes resins or latex that might entrap the female, egg, or newly hatched larvae or might compromise egg respiration $(6,88)$. These physical limits on egg laying also factor into the timing of oviposition (see below).

Most gall-forming tephritids studied thus far lay their eggs when the host plant is generating new vegetative growth [i.e. early aggregative attack (134)]. Eggs are deposited in or near buds on recent vegetative growth or, in the case of florivorous species, in the immature flower heads. Thus, the window for oviposition suitability on a host plant may be very narrow. The adaptive constraints of the timing of oviposition is exemplified by Trupanea bisetosa, the females of which lay their eggs in immature flower heads of the host plant, Helianthus annuus (89). These females must avoid piercing plant tissues during oviposition or risk becoming entrapped in resinous exudates from wounds. Older flower heads produce much more resin than younger flower heads.

The size, shape, and color of a particular ovipositional resource, such as a flower head, or the overall shape, developmental stage, or height of a host plant can influence oviposition preferences of females and the number of eggs laid and thus the local population structure. Females of Tephritis bardanae used the external dimensions of the flower heads of Arctium minus as ovipositional cues, 
evidencing an acceptance of smaller sized heads (116). Conversely, Cerajocera tussilaginis oviposited in larger heads of $A$. minus near anthesis. Site suitability for oviposition was 10-11 days for both tephritid species, without overlap; thus the two sympatric species temporally separated their shared resource by differences in ovipositional constraints (116).

Laboratory studies of Chaetorellia australis from Centaurea solstitialis showed that the size, shape, and color of artificial flower heads had some effect on oviposition preferences (104). Other plant qualities such as height have also been implicated in ovipositional preferences (120).

Females of $E$. solidaginis were able to distinguish between 38 distinct, naturally occurring clones or genotypes of Solidago altissima in field studies (1). Thus, discrimination among hosts, even among small groups of individuals, by gravid females plays a major role in the distribution and abundance of local populations of this tephritid.

CLUTCH SIZE This character includes the number of eggs deposited by a single female during an ovipositional event and during supernumerary oviposition in the same resource. Nonfrugivorous tephritids lay eggs either singly or in clutches of 2-16. There is no clear pattern or predictive value for how many eggs a given species will lay per oviposition episode. Flower head-infesting species lay eggs singly or in clutches of up to $13(75,76)$. One third of gallforming species studied to date lay eggs in clutches of 2-16; the majority lay eggs singly. Even if more than one egg is laid, some species still may separate as first instars and develop individually within the resource $(58,59)$; therefore, gregariousness is not necessarily predicated on initial clutch size.

Clutch size relative to extrinsic factors such as patch exploitation, dispersal or allocation of resources, and survivorship has been examined for several tephritid species. Zwölfer \& Arnold-Rinehart $(136,137)$ showed that for U. cardui, a monophage that forms multi-locular galls in the flower heads of Cirsium arvense in Europe, greater numbers of individuals per gall increased the chance of escaping parasitism. As the number of larvae per gall increased, so did gall size. Subsequently, more nutrients were channeled into the larger galls, which led to larger larvae, which finally conferred greater fitness to the adults. However, field data showed clutch sizes to be highly variable with 1-25 eggs. Freese $\&$ Zwölfer (17) examined clutch size in this system from the perspective of optimality theory, which assumes that increasing clutch size in a finite resource reduces offspring survival. They determined that females of $U$. cardui were able to assess the ovipositional resource quality and deposit more or fewer eggs depending on axillary bud size. Further, they noted that females are timelimited, rather than egg-limited, as females are relatively short-lived, and thus favor oviposition of large clutches when an appropriate resource is found. They hypothesized that the risks of laying large clutches in only a few sites could be 
ameliorated by laying fewer eggs in a greater number of axillary buds; thus, females would be expected to exhibit a high degree of plasticity in oviposition strategy, depending on the resource quality and an individual's age.

T. conura oviposits exclusively on young buds of its host, $C$. heterophyllum in Europe (108). In this system, eggs were shown to be laid in clutches randomly across a patch of host plants. This distribution was determined by the short time frame for oviposition suitability of the host plant, which also reduced the chances of multiple ovipositions within a given patch.

Lalonde \& Roitberg (91) discovered that females of Orellia ruficauda on C. arvense, a monoecious thistle, oviposit during a narrow window of flower head development (the day before blossom). The larvae feed only on achenes in female flower heads, and achene production is pollen-limited. Field studies showed that large clutches of eggs were not laid in female flower heads in local patches where male plants were absent (92).

SUPERNUMERARY OVIPOSITION Trupanea nigricornis females laid eggs singly, but they oviposited a multiplicity of times in the same flower head (89). As the season progressed and resources for oviposition became more scarce, the tendency for multiple ovipositions into a single flower head increased (1-5 eggs per head early in the season, 10-27 eggs per head late). The use of ovipositiondeterring substances by females has been shown to reduce multiple clutches in flower heads, thus limiting competition for resources (91). The logical extension that oviposition-deterring substances would then lead to greater dispersal of eggs over a wider area was supported by laboratory data, but field data did not corroborate these findings (117).

\section{Larvae}

According to the category III generalities (133), larval development lasts from 20-40 days. The role of diapause and its contribution to the duration of any particular stage has not been discussed. See the Ecology section above for a review of research conducted on intrinsic factors such as enemy-free space, intraspecific and interspecific competition, nutritional suitability, and timing of diapause. The larvae of tephritids are extraordinary in the intricate ways that they spatially and temporally partition resources. Zwölfer $(132,133)$ gave rise to this idea, and in describing the trophic strategies of California's tephritids, we have found that tephritid evolution in terms of resource utilization has been one of selection toward avoidance of competition for resources (79).

First instars generally feed near the area of egg deposition, but they have the ability to tunnel relatively long distances away from the site of oviposition to a food resource (70). First instars of flower head-feeding tephritids are often found tunneling through one to several florets or small ovules. First instars of gall-forming or branch- or stem-mining tephritids usually confine their feeding 
to relatively small areas. The first instars of European thistle flower head gallforming tephritids often tunnel into and feed on ovules or receptacle tissues where gall formation takes place. The formation of galls has been examined for several species, mainly those used as agents for biological control of weeds (70), and studies show that larval feeding and in some cases larval secretions are necessary for the induction of gall tissue. In contrast, the first instars of Aciurina trixa tunnel into the branch to feed while gall induction proceeds in the nearby axillary bud not mined by this larva (82).

The duration of the first instar is typically short, lasting about one week. The first instars of Aciurina and certain Procecidochares spp., however, overwinter as first instars inside an incipient gall. In these cases the first instar is the longest life stage and lasts up to 8 months, or even 20 months if lack of winter rainfall locally fails to stimulate host plant growth $(55-58,60,82)$.

Little is known about second instars; this stage appears to be of uniformly short duration within the tephritines. Feeding usually appears to be a continuation of what was initiated by first instars and bridges the type and heaviest quantity of feeding done by the third instar.

The third instar may exhibit complex feeding behaviors, and it often has associated changes in feeding habits or niches (see Facultative Niche Exploitation above). The third instar is also the stage when the most biomass is consumed and gained. The third instar of gall-forming or similarly endophagous species is also responsible for the construction of an exit tunnel for subsequent adult emergence. Some species, such as $O$. occidentalis (51) and Campiglossa (=Paroxyna) genalis (39), exit flower heads to pupariate in the soil. This method of pupariation is far more common among frugivorous species (126). The third instar is generally the longest larval developmental stage, except as noted above, and for those species overwintering in flower heads, it may be the longest life stage (79).

\section{BIOLOGY OF THE ADULT}

The longevity of adult nonfrugivorous tephritids has been generalized as relatively short, except for those species that overwinter as adults (133). We have found that adults of some aggregative species are long-lived, living up to a year in laboratory cages and in nature (79). Adults of circumnatal species are generally short-lived for up to about one month (79).

Sexually dimorphic wing patterns were known for some Trupanea spp. among nonfrugivorous North American Tephritidae (15) and were just recently discovered in the genera Aciurina (55-57), Procecidochares (58), and Xenochaeta (RD Goeden \& JA Teerink, unpublished data). Furthermore, certain species of Aciurina show geographic variation in the incidence and degrees of expression of this dimorphism (55-57). 
The reproductive behavior of nonfrugivorous tephritid adults has recently been thoroughly reviewed by Headrick \& Goeden (79) with comparisons made between frugivorous and nonfrugivorous species. The major topics discussed comprehensively were wing displays; courtship behaviors including wing displays, aggregation displays, body appendage displays, and trophallaxis; copulation behaviors; and oviposition. New theories were presented concerning the evolution of tephritid mating systems. In all species studied, females exhibited final choice in the copulation decision. A tephritid male cannot gain intromission unless a female first exserts her aculeus, thus exposing the gonopore (79).

The majority of nonfrugivorous species studied are aggregative and display a variety of mating strategies, including resource defense polygyny, and paternal assurance strategies, including mate guarding, male combat, and lengthy copulation durations (79). A combination of selection pressures, such as hostplant phenology, distribution and abundance, resource utilization, male-male competition, and female choice, most likely contribute to the diversity of sexual behaviors and mating systems observed in nonfrugivorous tephritid species.

Interspecific factors also overlie intraspecific interactions. The types of aggregation and courtship behaviors displayed by nonfrugivorous tephritids have been hypothesized to be important isolating mechanisms, especially for sympatric sibling species. However, some closely related sympatric species exhibit little in the way of pre-mating isolation mechanisms (89), and other species that have complex and fixed aggregation and courtship displays occur in nature isolated in space and time from other closely related nonfrugivorous species $(76,80)$.

Substantial progress in our knowledge of nonfrugivorous tephritids has been made over the last decade, including the development of hypotheses regarding evolutionary biology, resource utilization, and mating systems, but again, the lack of phylogenetic relationships hampers our ability to make robust generalizations above the generic level. Further studies on their evolutionary biology, systematics, and behavior will aid in substantiating and modifying our current knowledge of this interesting group of flies.

\section{Literature Cited}

1. Anderson SS, McCrea KD, Abrahamson WG, Hartzel LM. 1989. Host genotype choice by the ball gallmaker Eurosta solidaginis (Diptera: Tephritidae). Ecology 70:1048-54

2. Bateman MA. 1972. The ecology of fruit flies. Annu. Rev. Entomol. 17:493-518

3. Baust JG, Nishino M. 1991. Freezing tolerance in the goldenrod gall fly (Eurosta solidaginis). In Insects at Low Temperature, ed. RE Lee, DL Denlinger, pp. 26075. New York/London: Chapman \& Hall 
4. Belcari A. 1986. Contributi alla conoscenza dei ditteri tefritidi. III. Descrizione della larva matura de Phagocarpus permundus (Harris) (Diptera Tephritidae). Frust. Entomol. 9:77-106

5. Belcari A. 1987. Contributi alla conoscenza dei ditteri tefritidi. IV. Descrizione della larva di terza etá di Acanthiophilus helianthi (Rossi), Dacus oleae (Gmel.), Ceratitis capitata (Wied.), Acidia cognata Wied. e considerazioni preliminari sulle differenziazioni morfologiche legate al diverso trofismo. Frust. Entomol. 10:83-125

6. Berube DE. 1978. Larval descriptions and biology of Tephritis dilacerata (Diptera: Tephritidae), a candidate for the biocontrol of Sonchus arvensis in Canada. Entomophaga 23:69-82

7. Bremer K. 1994. Asteraceae Cladistics and Classification. Portland, OR: Timber. $752 \mathrm{pp}$.

8. Christensen LD, Foote RH. 1960. Biology of fruit flies. Annu. Rev. Entomol. 5:17192

9. Cogan BH, Munro HK. 1983. Family Tephritidae. In Catalogue of the Diptera of the Afrotropical Region, ed. RW Crosskey, pp. 518-54. London: Br. Mus. Nat. Hist.

10. Compton SG, Lawton JH, Rashbrook VK. 1989. Regional diversity, local community structure and vacant niches: the herbivorous arthropods of bracken in South Africa. Ecol. Entomol. 14:365-73

11. Cook EF. 1949. The evolution of the head in the larvae of the Diptera. Microentomology 14:1-57

12. Craig TP, Itami JK, Abrahamson WG, Horner JD. 1994. Behavioral evidence for host-race formation in Eurosta solidaginis. Evolution 47:1696-710

13. Ferrar P. 1987. A Guide to the Breeding Habits and Immature Stages of Diptera Cyclorrapha, Vol. 8, Parts I \& II. Leiden: Brill Scand. Sci.

14. Foote RH, Blanc FL. 1963. The fruit flies or Tephritidae of California. Calif. Insect Surv. Bull. 7:1-117

15. Foote RH, Blanc FL, Norrbom AL. 1993. Handbook of the Fruit Flies (Diptera: Tephritidae) of America North of Mexico. Ithaca, NY/London: Comstock. 571 pp.

16. Foote RH, Steyskal GC. 1987. Tephritidae. In Manual of Nearctic Diptera, ed. JF McAlpine, BV Peterson, GE Shewell, HJ Teskey, JR Vockeroth, DM Wood, 2:81731. Res. Branch Agric. Can. Monogr. No. 27

17. Freese G, Zwölfer H. 1996. The problem of optimal clutch size in a tritrophic system: the oviposition strategy of the thistle gallfly Urophora cardui (Diptera, Tephritidae). Oecologiaf 108:293-302

18. Freidberg A. 1984. Gall Tephritidae. In Biology of Gall Insects, ed. TN Ananthakrishnan, pp. 129-67. London: Arnold

19. Freidberg A. 1991. A new species of Ceratitis (Ceratitis ) (Diptera: Tephritidae), key to species of subgenera Ceratitis and Pterandrus, and record of Pterandrus fossil. Bishop Mus. Occas. Pap. 31:16673

20. Freidberg A, Kluger J. 1989. Diptera: Tephritidae. Fauna Palest. Insecta 4:1212

21. Goeden RD. 1978. Biological control of weeds. Part II. In Introduced Parasites and Predators of Arthropod Pests and Weeds, USDA Handb. 480, ed. Clausen CP, pp. 357-545

22. Goeden RD. 1985. Host-plant relations of Trupanea spp. (Diptera: Tephritidae) in southern California. Proc. Entomol. Soc. Wash. 87:564-71

23. Goeden RD. 1987. Life history of Trupanea conjuncta (Adams) on Trixis californica Kellogg in southern California (Diptera: Tephritidae). Pan-Pac. Entomol. 63:284-91

24. Goeden RD. 1987. Host-plant relations of native Urophora spp. (Diptera: Tephritidae) in southern California. Proc. Entomol. Soc. Wash. 89:269-74

25. Goeden RD. 1988. Life history of Trupanea imperfecta (Coquillett) on Bebbia juncea (Bentham) Greene in the Colorado Desert of southern California (Diptera: Tephritidae). Pan-Pac. Entomol. 64:34551

26. Goeden RD. 1988. Gall formation by the capitulum-infesting fruit fly, Tephritis stigmatica (Diptera: Tephritidae). Proc. Entomol. Soc. Wash. 90:37-43

27. Goeden RD. 1989. Host-plants of Neaspilota in California (Diptera: Tephritidae). Proc. Entomol. Soc. Wash. 91:164-68

28. Goeden RD. 1990. Notes on the life history of Eutreta simplex Thomas on Artemisia ludoviciana Nuttall in southern California (Diptera: Tephritidae). PanPac. Entomol. 66:33-38

29. Goeden RD. 1992. Analysis of known and new host records for Trupanea from California (Diptera: Tephritidae). Proc. Entomol. Soc. Wash. 94:107-18

30. Goeden RD. 1993. Analysis of known and new host records of Tephritis from California and a description of a new species, T. joanae (Diptera: Tephritidae). Proc. Entomol. Soc. Wash. 95:425-34 
31. Goeden RD. 1994. Analysis of known and new host records for Paroxyna from California (Diptera:Tephritidae). Proc. Entomol. Soc. Wash. 96:288-300

32. Goeden RD, Blanc FL. 1986. New synonymy, host, and California records in the genera Dioxyna and Paroxyna (Diptera: Tephritidae). Pan-Pac. Entomol. 62:8890

33. Goeden RD, Headrick DH. 1990. Notes on the biology and immature stages of Stenopa affinis Quisenberry (Diptera: Tephritidae). Proc. Entomol. Soc. Wash. 92:641-48

34. Goeden RD, Headrick DH. 1991. Notes on the biology, hosts, and immature stages of Tomoplagia cressoni Aczél in southern California (Diptera: Tephritidae). Proc. Entomol. Soc. Wash. 93:549-58

35. Goeden RD, Headrick DH. 1991. Life history and descriptions of immature stages of Tephritis baccharis (Coquillett) on Baccharis salicifolia (Ruiz \& Pavon) Persoon in southern California. Pan-Pac. Entomol. 67:86-98

36. Goeden RD, Headrick DH. 1992. Life history and description of immature stages of Neaspilota viridescens Quisenberry (Diptera: Tephritidae) on native Asteraceae in southern California. Proc. Entomol. Soc. Wash. 94:59-77

37. Goeden RD, Headrick DH, Teerink JA. 1993. Life history and descriptions of immature stages of Tephritis arizonaensis Quisenberry on Baccharis sarothroides Gray in southern California (Diptera: Tephritidae). Proc. Entomol. Soc. Wash. 95:210-22

38. Goeden RD, Headrick DH, Teerink JA. 1994. Life history and description of immature stages of Procecidochares flavipes Aldrich (Diptera: Tephritidae) on Brickellia spp. in southern California. Proc. Entomol. Soc. Wash. 96:288-300

39. Goeden RD, Headrick DH, Teerink JA. 1994. Life history and description of immature stages of Paroxyna genalis (Thomson) (Diptera: Tephritidae) on native Asteraceae in southern California. Proc. Entomol. Soc. Wash. 96:612-29

40. Goeden RD, Headrick DH, Teerink JA. 1995. Life history and description of immature stages of Valentibulla californica (Coquillett) (Diptera: Tephritidae) on Chrysothamnus nauseosus (Pallas) Britton in southern California. Proc. Entomol. Soc. Wash. 97:548-60

41. Goeden RD, Headrick DH, Teerink JA. 1995. Life history and description of immature stages of Urophora timberlakei Blanc \& Foote (Diptera: Tephritidae) on native Asteraceae in southern California. Proc. Entomol. Soc. Wash. 97:779-90

42. Goeden RD, Ricker DW. 1974. The phytophagous insect fauna of the ragweed, Ambrosia acanthicarpa, in southern California. Environ. Entomol. 3:827-34

43. Goeden RD, Ricker DW. 1974. The phytophagous insect fauna of the ragweed, Ambrosia chamissonis, in southern California. Environ. Entomol. 3:835-39

44. Goeden RD, Ricker DW. 1975. The phytophagous insect fauna of the ragweed, Ambrosia confertiflora, in southern California. Environ. Entomol. 4:301-6

45. Goeden RD, Ricker DW. 1976. The phytophagous insect fauna of the ragweed, Ambrosia dumosa, in southern California. Environ. Entomol. 5:45-50

46. Goeden RD, Ricker DW. 1976. The phytophagous insect faunas of the ragweeds, Ambrosia chaenopodifolia, A eriocentra, and $A$. ilicifolia in southern California. Environ. Entomol. 5:923-30

47. Goeden RD, Ricker DW. 1976. The phytophagous insect fauna of the ragweed, Ambrosia psilostachya, in southern California. Environ. Entomol. 5:1169-77

48. Goeden RD, Ricker DW. 1986. Phytophagous insect fauna of the desert shrub Hymenoclea salsola in southern California. Ann. Entomol. Soc. Am. 79:39-47

49. Goeden RD, Ricker DW. 1986. Phytophagous insect faunas of two introduced Cirsium thistles, $C$. ochrocentrum and $C$. vulgare, in southern California. Ann. Entomol. Soc. Am. 79:945-52

50. Goeden RD, Ricker DW. 1986. Phytophagous insect faunas of the two most common native Cirsium thistles, C. californicum and $C$. proteanum, in southern California. Ann. Entomol. Soc. Am. 79:953-62

51. Goeden RD, Ricker DW. 1987. Phytophagous insect faunas of the native thistles Cirsium brevistylum, Cirsium congdonii, Cirsium occidentale, and Cirsium tioganum, in southern California. Ann. Entomol. Soc. Am. 80:152-60

52. Goeden RD, Ricker DW. 1987. Phytophagous insect faunas of native Cirsium thistles, C. mohavense, C. neomexicanum, and $C$. nidulum, in the Mojave Desert of southern California. Ann. Entomol. Soc. Am. 80:161-75

53. Goeden RD, Ricker DW. 1989. Phytophagous insect faunas of the desert shrubs Bebbia juncea and Trixis californica in southern California. Ann. Entomol. Soc. Am. 82:325-31

54. Goeden RD, Teerink JA. 1993. Phytophagous insect faunas of Dicoria 
canescens and Iva axillaris, native relatives of ragweeds, Ambrosia spp., in southern California, with analyses of insect associates of Ambrosiinae. Ann. Entomol. Soc. Am. 86:37-50

55. Goeden RD, Teerink JA. 1996. Life histories and descriptions of adults and immature stages of two cryptic species, Aciurina ferruginea (Doane) and $A$. michaeli, new species (Diptera: Tephritidae), on Chrysothamnus viscidiflorus (Hooker) Nuttall in southern California. Proc. Entomol. Soc. Wash. 98:415-38

56. Goeden RD, Teerink JA. 1996. Life history and descriptions of adults and immature stages of Aciurina idahoensis Steyskal (Diptera: Tephritidae) on Chrysothamnus viscidiflorus (Hooker) Nuttall in southern California. Proc. Entomol. Soc. Wash. 98:681-94

57. Goeden RD, Teerink JA. 1996. Life history and descriptions of adults and immature stages of Aciurina semilucida (Bates) (Diptera: Tephritidae) on Chrysothamnus viscidiflorus (Hooker) Nuttall in southern California. Proc. Entomol. Soc. Wash. 98:752-66

58. Goeden RD, Teerink JA. 1997. Life histories and descriptions of adults and immature stages of Procecidochares kristineae and $P$. lisae new spp. (Diptera: Tephritidae) on Ambrosia spp. in southern California. Proc. Entomol. Soc. Wash. 99:6788

59. Goeden RD, Teerink JA. 1997. Life history and description of immature stages of Procecidochares anthracina (Doane) (Diptera: Tephritidae) on Solidago californica Nuttall in southern California. Proc. Entomol. Soc. Wash. 99:180-93

60. Green JF, Headrick DH, Goeden RD. 1993. Life history and description of immature stages of Procecidochares stonei Blanc \& Foote on Viguiera spp. in southern California (Diptera: Tephritidae). Pan-Pac. Entomol. 69:18-32

61. Han HY, McPheron BA. 1994. Phylogenetic study of selected tephritid flies (Insecta: Diptera: Tephritidae) using partial sequences of the nuclear $18 \mathrm{~S}$ ribosomal DNA. Biochem. Syst. Ecol. 22:447-57

62. Hancock DL. 1984. Ceratitinae (Diptera: Tephritidae) from the Malagasy Subregion. J. Dep. Agric. Circ. 103. 20 pp.

63. Hancock DL. 1985. Trypetinae (Diptera: Tephritidae) from Madagascar. J.Entomol. Soc. S. Afr. 48:283-301

64. Hancock DL. 1986. Classification of the Trypetinae (Diptera: Tephritidae), with a discussion of the Afrotropical fauna. $J$. Entomol. Soc. S. Afr. 49:275-305
65. Hardy DE. 1977. Family Tephritidae (Trypetidae, Trupaneidae). In A Catalog of the Diptera of the Oriental Region. Vol. 3, Suborder Cyclorrhapha (Excluding Division Aschiza), ed. MD Delfinado, DE Hardy, pp. 44-134. Honolulu: Univ. Hawaii

66. Hardy DE, Foote RH. 1989. Family Tephritidae. In Catalog of the Diptera of the Australasian and Oceanic Regions, Bishop Mus. Spec. Publ. 86, ed. NL Evanhuis, pp. 503-31. Honolulu: Bishop Mus.

67. Harris P. 1989. The use of Tephritidae for the biological control of weeds. Biocontrol News Inf. 10:7-16

68. Harris P. 1989. Feeding strategy, coexistence and impact of insects in spotted knapweed capitula. In Proc. Int. Symp. Biol. Control Weeds, ed. ES Delfosse, 7:39-47. Rome: Inst. Sper. Patol. Veg.

69. Harris P. 1991. Classical biocontrol of weeds: its definition, selection of effective agents, and administrative-political problems. Can. Entomol. 123:827-49

70. Harris P, Shorthouse JD. 1996. Effectiveness of gall inducers in weed biological control. Can. Entomol. 128:1021-55

71. Hartley SE, Lawton JH. 1992. Host-plant manipulation by gall-insects: a test of the nutrition hypothesis. J. Anim. Ecol. 61:113-19

72. Hawkins BA. 1988. Do galls protect endophytic herbivores from parasitoids? A comparison of galling and non-galling Diptera. Ecol. Entomol. 13:473-77

73. Headrick DH, Goeden RD. 1989. Life history of Pteromalus coloradensis (Ashmead) (Hymenoptera: Pteromalidae) a parasite of Paracantha gentilis Hering (Diptera: Tephritidae) in Cirsium thistle capitula. Proc. Entomol. Soc. Wash. 91:594-603

74. Headrick DH, Goeden RD. 1990. Description of the immature stages of Paracantha gentilis Hering (Diptera: Tephritidae). Ann. Entomol. Soc. Am. 83:220-29

75. Headrick DH, Goeden RD. 1990. Resource utilization by larvae of Paracantha gentilis (Diptera: Tephritidae) in capitula of Cirsium californicum and C. proteanum (Asteraceae) in southern California. Proc. Entomol. Soc. Wash. 92:512-20

76. Headrick DH, Goeden RD. 1990. Life history of Paracantha gentilis (Diptera: Tephritidae). Ann. Entomol. Soc. Am. 83:776-85

77. Headrick DH, Goeden RD. 1991. Life history and descriptions of immature stages of Trupanea californica Malloch (Diptera: Tephritidae) on Gnaphalium spp. (Asteraceae) in southern California. 
Proc. Entomol. Soc. Wash. 93:559-70

78. Headrick DH, Goeden RD. 1993. Life history and description of immature stages of Aciurina thoracica Curran (Diptera: Tephritidae) on Baccharis sarothroides in southern California. Ann. Entomol. Soc. Am. 86:68-79

79. Headrick DH, Goeden RD. 1994. Reproductive behavior of California fruit flies and the classification and evolution of Tephritidae (Diptera) mating systems. Stud. Dipterol. 1:194-252

80. Headrick DH, Goeden RD, Teerink JA. 1995. Life history and description of immature stages of Euaresta stigmatica (Diptera: Tephritidae) on Ambrosia spp. (Asteraceae) in southern California. Ann. Entomol. Soc. Am. 88:58-71

81. Headrick DH, Goeden RD, Teerink JA. 1996. Life history and description of immature stages of Dioxyna picciola (Bigot) (Diptera: Tephritidae) on Coreopsis spp. (Asteraceae) in southern California. Proc. Entomol. Soc. Wash. 98:332-49

82. Headrick DH, Goeden RD, Teerink JA. 1997. Taxonomy of Aciurina trixa Curran (Diptera: Tephritidae) and its life history on Chrysothamnus nauseosus (Pallas) Britton in southern California; with notes on A. bigeloviae (Cockerell). Proc. Entomol. Soc. Wash. 99:415-28

83. Hilgendorf JH, Goeden RD. 1983. Phytophagous insect faunas of spiny clotbur, Xanthium spinosum, and cocklebur, Xanthium strumarium, in southern California. Environ. Entomol. 12:404-11

84. Joanisse DR, Storey KB. 1995. Temperature acclimation and seasonal responses by enzymes in cold-hardy gall insects. Arch. Insect Biochem. Physiol. 28:33949

85. Julien MH. 1992. Biological Control of Weeds: A World Catalogue of Agents and Their Target Weeds. London: Commonw. Agric. Bur. 186 pp. 3rd ed.

86. Kapoor VC. 1993. Indian Fruit Flies: Insecta: Diptera: Tephritidae. New York: Int. Sci.

87. King RC. 1970. Ovarian Development in Drosophila melanogaster. New York: Academic

88. Knio KM, Goeden RD, Headrick DH. 1996. Descriptions of immature stages of Trupanea nigricornis and T. bisetosa (Diptera: Tephritidae) from southern California. Ann. Entomol. Soc. Am. 89:111

89. Knio KM, Goeden RD, Headrick DH. 1996. Comparative biologies of the cryptic, sympatric species, Trupanea bisetosa and T. nigricornis (Diptera: Tephri- tidae) in southern California. Ann. Entomol. Soc. Am. 89:252-60

90. Labeyrie T. 1971. Trophic relations and sex meetings in insects. Acta Phytopathol. Acad. Sci. Hung. 6:229-34

91. Lalonde RG, Roitberg BD. 1992. Host selective behavior of a thistle-feeding fly: choices and consequences. Oecologia 90:534-39

92. Lalonde RG, Roitberg BD. 1994. Pollen availability, seed production and seed predator clutch size in a tephritid-thistle system. Evol. Ecol. 8:188-95

93. Lamp WD, McCarty MK. 1982. Biology of predispersal seed predators of the platte thistle, Cirsium canescens. J. Kans. Entomol. Soc. 55:305-16

94. Lawton JH. 1976. The structure of the arthropod community on bracken. Bot. J. Linn. Soc. 73:187-216

95. Lawton JH. 1982. Vacant niches and unsaturated communities: a comparison of bracken herbivores at sites on two continents. J. Anim. Ecol. 51:573-75

96. Ludwig CE. 1949. Embryology and morphology of the larval head of Calliphora erythrocephala Meigen. Microentomology 14:75-111

97. Margaritis LH. 1985. Comparative study of the eggshell of the fruit flies Dacus oleae and Ceratitis capitata. Can. J. Zool. 63:2194-206

98. Matsuda R. 1965. Morphology and evolution of the insect head. Mem. Am. Entomol. Soc. 4:1-334

99. Menees JH. 1962. The skeletal elements of the gnathocephalon and its appendages in the larvae of higher Diptera. Ann. Entomol. Soc. Am. 55:607-18

100. Merz B. 1994. Diptera Tephritidae. Insecta Helvetica. Geneva: Mus. Hist. Nat.

101. Mouzaki DG, Margaritis LH. 1991. Choriogenesis in the medfly Ceratitis capitata (Wiedemann) (Diptera: Tephritidae). Int. J. Insect Morphol. Embryol. 20:51-68

102. Mouzaki DG, Zarani FE, Margaritis LH. 1991. Structure and morphogenesis of the eggshell and micropylar apparatus in the olive fly, Dacus oleae (Diptera: Tephritidae). J. Morphol. 209:39-52

103. Norrbom AL. 1994. New genera of Tephritidae (Diptera) from Brazil and Dominican amber, with phylogenetic analysis of the tribe Ortalotrypetini. Insecta Mundi 8:1-16

104. Pittara IS, Katsoyannos BI. 1992. Effect of shape, size and color on selection of oviposition sites by Chaetorellia australis. Entomol. Exp. Appl. 63:10513 
105. Robinson AS, Hooper GHS, eds. 1989. Fruit Flies: Their Biology, Natural Enemies and Control. World Crop Pests, Vol. 3A, B. Amsterdam: Elsevier

106. Romstöck M. 1987. Tephritis conura Loew (Diptera: Tephritidae) and Cirsium heterophyllum (L.) Hill (Cardueae). Struktur- und Funktionsanalyse eines ökologischen Kliensystems. PhD thesis. Nat. Sci., Bayreuth, Bayreuth Univ. 147 pp.

107. Romstöck-Vockl M. 1990. Host refuges and spatial patterns of parasitism in an endophytic host-parasitoid system. Ecol. Entomol. 15:321-31

108. Romstöck-Vock1 M, Wissel C. 1989. Spatial and seasonal patterns in the egg distribution of Tephritis conura (Diptera: Tephritidae). Oikos 55:165-74

109. Snodgrass RE. 1924. Anatomy and metamorphosis of the apple maggot, Rhagoletis pomonella Walsh. J. Agric. Res. 28:1-36

110. Snodgrass RE. 1953. The Metamorphosis of a Fly's Head. Smithson. Misc. Collect. 122 No. 3. Washington, DC: Smithson. Inst.

111. Steck GJ. 1984. Chaetostomella undosa (Diptera: Tephritidae): biology, ecology, and larval description. Ann. Entomol. Soc. Am. 77:669-78

112. Stoltzfus WB. 1989. A non-gall forming Eurosta solidaginis (Diptera: Tephritidae). J. Iowa Acad. Sci. 96:50-51

113. Storey JM, Boggs KW, Good WR. 1992. Voltinism and phenological synchrony of Urophora affinis and U. quadrifasciata (Diptera: Tephritidae), two seed head flies introduced against spotted knapweed in Montana. Environ. Entomol. 21:105259

114. Storey JM, Good WR, Callan NW. 1993. Supercooling capacity of Urophora affinis and U. quadrifasciata (Diptera: Tephritidae), two flies released on spotted knapweed in Montana. Environ. Entomol. 22:831-36

115. Storey KB, Storey JM. 1988. Freeze tolerance in animals. Physiol. Rev. 68:27-84

116. Straw NA. 1989. The timing of oviposition and larval growth by two tephritid fly species in relation to host-plant development. Ecol. Entomol. 14:443-54

117. Straw NA. 1989. Evidence for an oviposition-deterring pheromone in Tephritis bardanae (Schrank) (Diptera: Tephritidae). Oecologia 78:121-30

118. Turner CE. 1996. Tephritidae in the biological control of weeds. In Fruit Fly Pests: A World Assessment of Their Biology and Management, ed. BA McPheron, GJ
Steck, pp. 157-64. Delray, FL: St. Lucie

119. Varley GC. 1937. The life history of some trypetid flies with descriptions of the early stages (Diptera). Proc. R. Entomol. Soc. London Ser. A 12:109-22

120. Walton R, Weis AE, Lichter JP. 1990. Oviposition behavior and response to plant height by Eurosta solidaginis (Fitch) (Diptera: Tephritidae). Ann. Entomol. Soc. Am. 83:509-14

121. Wan FH, Wang R. 1991. Achievements of biological weed control in the world and its prospect in China. Chin. J. Biol. Control 7:81-87

122. Wasbauer MS. 1972. An annotated host catalog of the fruit flies of America north of Mexico (Diptera: Tephritidae). Occas. Pap. Bur. Entomol. Calif. 19:1-172

123. Weis AE, Abrahamsom WG, Anderson MC. 1992. Variable selection on Eurosta's gall size, I: the extent and nature of variation in phenotypic selection. Evolution 46:1674-97

124. Weis AE, Abrahamsom WG, Anderson MC. 1994. Variable selection on Eurosta's gall size, II: a path analysis of the ecological factors behind selection. Evolution 48:734-45

125. Weis AE, Abrahamson WG, McCrea KD. 1985. Host gall size and oviposition success by the parasitoid Eurytoma gigantea. Ecol. Entomol. 10:341-48

126. White IM. 1988. Tephritid Flies Diptera: Tephritidae. Handbook for the Identification of British Insects, Vol. 10, Part 5a. London: R. Entomol. Soc. London. 134 pp.

127. White IM, Elson-Harris MM. 1992. Fruit Flies of Economic Significance: Their Identification and Bionomics. London: CAB Int.

128. Zarani FE, Margaritis LH. 1991. Ultrastructural features and formation of the micropylar apparatus in the cherry fly Rhagoletis cerasi. J. Morphol. 208:20514

129. Zwölfer H. 1965. Preliminary list of phytophagous insects attacking wild Cynareae (Compositae) species in Europe Tech. Bull. Commonw. Inst. Biol. Control 6:81-154

130. Zwölfer H. 1974. Innerartliche Kommunikations-systeme bei Bohrfliegen Biol. Unser Zeit. 4:146-53

131. Zwölfer H. 1974. Das Treffpunktprinzip als Kommunikationsstrategie und Isolationsmechanismus bei Bohrfliegen (Diptera: Trypetidae) Entomol. Ger. $1: 11-20$

132. Zwölfer H. 1979. Strategies and counterstrategies in insect population systems 
competing for space and food in flower heads and galls. Fortschr. Zool. 25:33153

133. Zwölfer H. 1983. Life systems and strategies of resource exploitation in tephritids. In Fruit Flies of Economic Importance, Proc. CEC/IOBC Int. Symp., ed. R Cavalloro, pp. 16-30. Rotterdam: Balkema

134. Zwölfer H. 1985. Insects and thistle heads: resource utilization and guild structure. In Proc. Int. Symp. Biol. Control Weeds, ed. ES Delfosse, 6:407-16. Vancouver: Agric. Can.

135. Zwölfer H. 1988. Evolutionary and ecological relationships of the insect fauna of thistles. Annu. Rev. Entomol. 33:10322
136. Zwölfer H, Arnold-Rinehart J. 1993. The evolution of interactions and diversity in plant-insect systems: the UrophoraEurytoma food web in galls on Palearctic Cardueae. In Biodiversity and Ecosystem Function, ed. ED Schulze, HA Mooney, pp. 211-33. Berlin/New York: Springer

137. Zwölfer H, Arnold-Rinehart J. 1994. Parasitoids as a driving force in the evolution of gall size of Urophora on Cardueae hosts. In Plant Galls, Syst. Assoc. Spec. Vol., ed. MAJ Williams, 49:245-57. Oxford: Clarendon

138. Zwölfer H, Harris P. 1971. Host specificity determination of insects for biological control of weeds. Annu. Rev. Entomol. $16: 159-78$ 